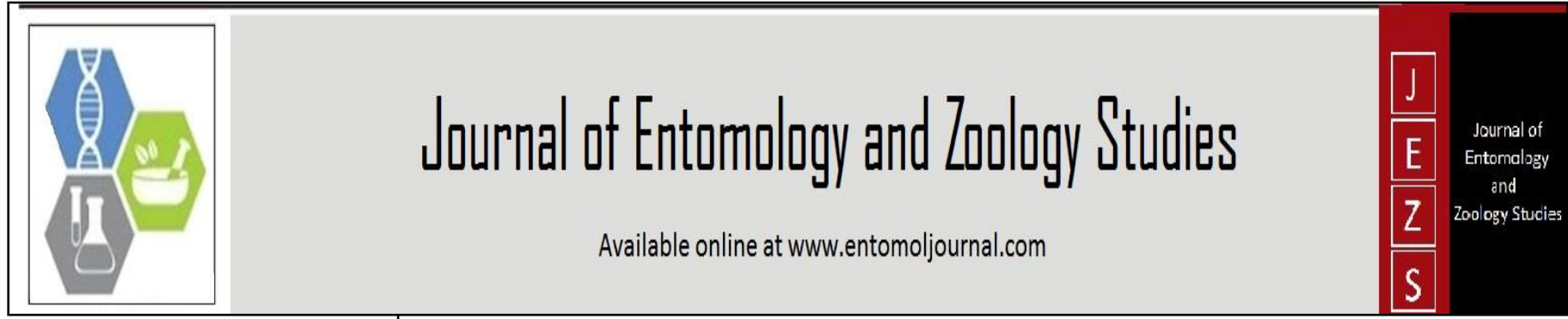

E-ISSN: 2320-7078

P-ISSN: 2349-6800

www.entomoljournal.com

JEZS 2021; 9(2): 110-116

(C) $2021 \mathrm{JEZS}$

Received: 13-01-2021

Accepted: 15-02-2021

Lucy Ingtipi

College of Fisheries, Assam

Agricultural University, Raha,

Nagaon, Assam, India

Sushanta Borthakur

College of Fisheries, Assam

Agricultural University, Raha,

Nagaon, Assam, India

Sangipran Baishya

College of Fisheries, Assam

Agricultural University, Raha,

Nagaon, Assam, India

Kaustubh Bhagawati

College of Fisheries, Assam

Agricultural University, Raha,

Nagaon, Assam, India
Corresponding Author: Sangipran Baishya

College of Fisheries, Assam

Agricultural University, Raha,

Nagaon, Assam, India

\section{Growth performance of Jayanti rohu with three species combination viz., Catla catla, Labeo rohita and Cirrhinus mrigala at different stocking densities}

\author{
Lucy Ingtipi, Sushanta Borthakur, Sangipran Baishya and Kaustubh \\ Bhagawati
}

DOI: $\underline{\text { https://doi.org/10.22271/j.ento.2021.v9.i2b.8652 }}$

\section{Abstract}

The present study was conducted to compare the growth performance of $9^{\text {th }}$ generation Jayanti rohu with non-Jayanti rohu cultured together with Catla catla and Cirrhinus mrigala at different stocking densities for 90 days The experiment was carried out in homogenous rectangular cement cisterns in the wet laboratory of College of Fisheries, Assam Agricultural University, Raha. Four treatments with three replicates viz. Treatment-I, Treatment-II, Treatment-III and Treatment Control (reference treatment) were taken. Ten numbers of fishes were stocked in each cistern. Jayanti rohu was stocked at the rate of $35 \%$, $40 \%, 45 \%$ and $0 \%$ in the treatments respectively. Non-Jayanti rohu was stocked at the rate of $40 \%$ in Control treatment The study revealed the effect of different stocking densities with better growth of Jayanti rohu in Treatment-I (35\% stocking density) where stocking density of catla and mrigal was 55\% and $10 \%$ respectively. The percentage weight gain of $9^{\text {th }}$ generation Jayanti rohu over non-Jayanti rohu showed $31.60 \%$ in Treatment-I followed by $17.13 \%$ in Treatment-II and lowest was recorded at $6.65 \%$ in Treatment-III treatment. The result indicates better performance of Jayanti rohu in terms of net weight gain, average daily growth rate, Food Conversion Ratio (FCR), Specific Growth Rate (SGR), survivability and production compared to non-Jayanti rohu.

Keywords: acclimatization, FCR, Jayanti rohu, non-jayanti riohu, SGR

\section{Introduction}

Aquaculture is considered as one of the fastest growing sector of the animal production industry. Fisheries and aquaculture are the important sources of food, nutrition, income and livelihoods for millions of people around the world. In Indian freshwater aquaculture scenario, carp culture is the major mainstay of fish production. The three Indian Major Carps (IMC), viz. Catla (Catla catla), Rohu (Labeo rohita) and Mrigal (Cirrhinus mrigala) contribute the bulk of production to the extent of 70 to 75 percent of the total fresh water fish production, followed by silver carp, grass carp, common carp, catfishes forming a second important group contributing the balance of 25 to 30 percent (FAO, 2014) ${ }^{[16]}$. In India, Indian major carps are the most important common commercial fishes, generating maximum market demand and acceptability as food by the consumers due to their taste and flesh. Among the Indian major carps, Rohu is one of the most preferred species in the country and fetches a higher price in the market.

India's first genetically improved rohu, Jayanti rohu with higher growth efficiency was released by Central Institute of Freshwater Aquaculture (CIFA), Bhubaneswar during 1997 on the occasion of 50 years of Indian independence (Swarna Jayanti). Morphologically it is similar to rohu but grows much faster than the normal rohu. The Jayanti rohu is recording $17 \%$ more growth per generation after five generations of selective breeding (Reddy, 2003; Das Mahapatra et al. 2007) ${ }^{[30,12]}$. When tested extensively in different farms, the performance of Jayanti rohu was found better than the other strains used by farmers which resulted in superior performance in terms of body weight and survival rate. On an average farm, the improved carp strain showed 15\% higher body weight at harvest in India and 36\% higher in Bangladesh (Dey et al. 2010) ${ }^{[13]}$. 
The improved strains are found to be more profitable than the existing carp strains. This would increase the profitability of a hatchery which can afford to pay a higher price for genetically-improved brood stock (Kumar et al. 2008) ${ }^{[24]}$. The culture of Jayanti rohu is preferred over the normal rohu due to its higher growth performance and disease resistance (Das Mahapatra, et al. 2007) ${ }^{[12]}$. The growth performance of Jayanti rohu in monoculture system was $38.16 \%$ higher than that of normal rohu in monoculture system after the culture period of 11 months. The growth performance of Jayanti rohu in composite fish culture system was $17.72 \%$ higher than that of normal rohu in monoculture system (Sharma, 2015) ${ }^{[39]}$.

\section{Materials and methods}

The experiment was conducted in homogenous cement cisterns $(2.6 \mathrm{~m} \times 1.50 \mathrm{~m} \times 1.75 \mathrm{~m})$ with treatments T- I, T- II, T- III and TC located in the wet laboratory of the College of Fisheries, Assam Agricultural University, Raha for a period of 90 days. 9th generation Jayanti rohu was stocked @35\%, 40\% and $45 \%$ in T- I, T- II and T- III treatments along with Catla catla and Cirrhinus mrigal as shown in Table 1.

Acclimatization was done for one week in the cement cisterns and fed with 1:1 mixture of rice polish and mustard oil cake. After seven days of fertilization, each tank was stocked with ten numbers of fishes. The length and weight of the fishes stocked were recorded. Cisterns were covered with nylon net to prevent escape of fishes. The reference treatment (TC) was stocked only with Non-Jayanti rohu. Each treatment was conducted in triplicate. The bottoms of the cisterns were provided with 6 " soil bed.

Cisterns were initially dried, cleaned and limed @ $500 \mathrm{~kg} \mathrm{ha}^{-1}$ and filled up with tap water to a depth of $1.2 \mathrm{~m} \pm 2 \mathrm{~cm}$. After 7 days of lime application, $0.01 \mathrm{~kg} \mathrm{~m}^{-3}$ Raw Cow dung (RCD), $0.035 \mathrm{~kg} \mathrm{~m}^{-3}$ Mustard oil cake (MOC) and $0.0025 \mathrm{~kg}$ $\mathrm{m}^{-3}$ Single Super Phosphate (SSP) were applied as initial dose. Mustard oil cake was soaked overnight and on the next day before application RCD and SSP were mixed along with overnight soaked MOC and then broadcasted throughout the tanks.

During the experimental period the fish were fed with pelleted feed containing 25\% crude protein twice daily @ 3\% body weight. The feed was given on trays which were provided on each cistern. The initial length and weight of the fish was recorded on the day of stocking and at fortnightly interval thereafter. Netting was done every fortnightly for checking fish weight and feed ration was adjusted accordingly.

The water quality parameters were analyzed on the day of stocking and thereafter at 15 days interval; during the entire experimental period following standard methods described by APHA, $2005^{[15]}$.

Table 1: Species combination and percentage of different species stocked

\begin{tabular}{|c|c|c|c|c|}
\hline \multirow{2}{*}{ Species } & \multicolumn{4}{|c|}{ Treatments } \\
\cline { 2 - 5 } & T-I & T-II & T-III & TC \\
\hline Jayanti rohu & $35 \%$ & $40 \%$ & $45 \%$ & - \\
\hline Non Jayanti rohu & - & - & - & $40 \%$ \\
\hline Catla & $55 \%$ & $50 \%$ & $45 \%$ & $50 \%$ \\
\hline Mrigal & $10 \%$ & $10 \%$ & $10 \%$ & $10 \%$ \\
\hline
\end{tabular}

\section{Results and Discussion}

The body weight gain of Jayanti rohu, non-Jayanti rohu, Catla catla and Cirrhinus mrigala of different treatments during culture periods are given in Table 2 . In terms of weight gain the highest growth was recorded in Jayanti rohu i.e. T-I treatment (35\% stocking density) where the stocking density of catla and mrigala was $55 \%$ and $10 \%$ respectively. The data pertaining to growth of Jayanti rohu, non-Jayanti rohu, Catla catla and Cirrhinus mrigala are presented in Table 3. From the study, it was revealed that the average net weight gain of Jayanti rohu was highest $(118.76 \pm 0.57 \mathrm{~g})$ in T-I treatment where stocking density (SD) was $35 \%$. The highest growth of Jayanti rohu in T-I treatment probably due to lower stocking density compared to T-II and T-III treatments. Similar results also reported by Sah et al. (2018) ${ }^{[34]}$ while conducting on the growth performance of genetically improved rohu and farmed rohu in Nepal. The percentage weight gain of $9^{\text {th }}$ generation Jayanti rohu over non-Jayanti rohu in the present finding showed $31.60 \%$ in T-I followed by $17.13 \%$ in T-II and lowest was recorded at $6.65 \%$ in T-III treatment. Das Mahapatra, et al. (2006) ${ }^{[10]}$ reported after four generations of selection, an average of $17 \%$ higher growth per generation was observed in improved rohu. Das Mahapatra et al. (2016) ${ }^{[11]}$ also acheived genetic gain of $18 \%$ per generation for growth trait after nine generations of selective breeding. It has also been reported that on an average, the improved carp strain gives $15 \%$ higher body weight at harvest in India and $36 \%$ higher in Bangladesh (Dey et al. 2010) ${ }^{[13]}$. In case of non Jayanti rohu, the average net weight gain showed $87.19 \pm 0.60 \mathrm{~g}$ in the reference treatment (TC) where stocking density was $40 \%$ which showed significant difference $(p<0.05)$ from T-I, T-II and TIII treatment. The results are comparable with Verma and Mandal, (2018) ${ }^{[40]}$ on evaluation of growth performance of common carp and mrigal with major carps in polyculture. Moreover in case of Catla catla, the average net weight gain was highest in T-III treatment $(96.20 \pm 0.35 \mathrm{~g})$ with $45 \%$ stocking density which coincide with the findings of Haque $e t$ al. (1993) ${ }^{[19]}$ who carried out an experiment on the effect of stocking densities in six nursery ponds and achieved best growth at lower stocking densities in Labeo rohita and Cirrhina mrigala. Average net weight gain of Catla showed no significant difference $(P>0.05)$ in TC and T-II treatment but differ significantly from T-I and T-III. Further, for Cirrhinus mrigala, the average net weight gain was highest $(70.38 \pm 0.67 \mathrm{~g})$ in reference treatment (TC) with same stocking density of $10 \%$ in all the treatments. Mrigal did not show significant difference $(P>0.05)$ in average net weight gain between T-I and T-II treatments and also between reference treatment (TC) and T-III but T-I and T-II showed significant different from reference treatment (TC) and T-III treatments. From the present study, it is evident that growth of mrigal is slow in comparison with rohu and catla. Similar results were also reported by Verma and Mandal, (2018) ${ }^{[40]}$ while evaluating growth performance of amur carp and mrigal with major carps in polyculture system.

In terms of feed conversion ratio (FCR), the highest value was found in case of Jayanti rohu $(1.56 \pm 0.01)$ in T-III treatment, followed by catla $(1.42 \pm 0.01)$ in reference treatment (TC), T-I and T-III treatments, mrigal $(1.39 \pm 0.02)$ in T-II treatment and non-Jayanti rohu $(1.34 \pm 0.03)$ in TC treatment. The FCR value of Jayanti rohu in T-III (1.56 \pm 0.01$)$ treatment with $45 \%$ stocking density was positively higher than T-II treatment (1.35 \pm 0.00$)$ with $40 \%$ stocking density and T-I treatment $(1.28 \pm 0.01)$ with $35 \%$ stocking density. Higher FCR value with increasing stocking density resulted less efficient utilization of food fry due to somatic growth (Ronald et al. 2014) ${ }^{[31]}$. The FCR value of Jayanti rohu showed significant difference $(P<0.05)$ among all the treatments. Sarkar, et al. 
(2015) ${ }^{[38]}$ reported more or less similar result that Jayanti rohu showed best FCR of 1.92 on diet containing $25 \%$ protein. Sahoo and Mukhopadhyay, (2008) ${ }^{[35]}$ reported best FCR for Jayanti rohu when fed with vitamin C @ 60mg/kg diet. But was found comparatively lower for non-Jayanti rohu, Catla, Mrigal. The FCR value of non-Jayanti rohu was $1.34 \pm 0.03$. Similar FCR value for non-Jayanti rohu was also reported by Manomaitis et al. (2004) [25]; Abid and Ahmed, (2009) ${ }^{[2]}$; Jahan, et al. (2013) ${ }^{[21]}$ and Basak et al. (2017) ${ }^{[6]}$. The FCR value of Catla obtained coincided with the findings of Ganesan, et al. (2015) ${ }^{[17]}$; Sachan, et al. (2016) ${ }^{[33]}$ and showed no significant difference $(P>0.05)$ among treatments. While for mrigal the highest FCR was obtained in T-II $(1.39 \pm 0.02)$ followed by T-I $(1.36 \pm 0.04)$, T-III $(1.29 \pm 0.01)$ and TC (1.26 \pm 0.01$)$. Results obtained were found more or less similar with the reported value of Hussain, et al. (2014) [20] and Priya Darsini, et al. (2014) ${ }^{[28]}$. Basak, et al. (2017) ${ }^{[6]}$ reported the FCR of mrigal ranged from 1.49 to 1.81 under carp polyculture with different stocking densities in Bangladesh. There showed no significant difference $(P>0.05)$ between T-I and T-III but TC and T-II differ significantly from the other treatments.

Jayanti rohu showed highest SGR value in T-I $(2.47 \pm 0.01 \%)$ followed by T-II $(2.40 \pm 0.00 \%)$ and T-III (2.24 \pm 0.04$)$ which was comparatively low than reported by Sarkar et al. (2015) ${ }^{[38]}$ and Sah, et al. (2018) ${ }^{[34]}$. Low SGR value for genetically improved rohu was also reported by Sahoo and Mukhopadhyay (2008) [35] when fed with $46.25 \%$ crude protein. The SGR of Jayanti rohu did not differ significantly $(P>0.05)$ between T-I and T-II treatment but differ significantly from T-III. Non-Jayanti rohu showed SGR value of $2.07 \pm 0.02 \%$ and is more or less comparable to the values obtained by Kohinoor et al. (2005) ${ }^{[23]}$; Basak et al. (2017) ${ }^{[6]}$; Sah et al. (2018) ${ }^{[34]}$ and Verma and Mandal, (2018) ${ }^{[40]}$. SGR value of Catla was highest in T-III $(2.13 \pm 0.01 \%)$ followed by T-II $(2.11 \pm 0.03 \%)$, TC $(2.08 \pm 0.02 \%)$ and T-I $(2.05 \pm 0.01 \%)$. Samad et al. (2017) ${ }^{[36]}$ reported highest SGR value in lowest SD and lowest SGR at highest SD. Verma and Mandal, (2018) ${ }^{[40]}$ reported $1.39 \%$ SGR on polyculture system. The SGR of catla did not differ significantly $(P>0.05)$ among different treatments. The SGR of mrigal was found to be highest in TC $(1.98 \pm 0.02 \%)$ and lowest in T-I $(1.81 \pm 0.05 \%)$. Basak, et al. (2017) ${ }^{[6]}$ reported the SGR of mrigal ranged from 1.04 to 1.07 under carp polyculture with different stocking densities. Verma and Mandal, (2018) ${ }^{[40]}$ found SGR of $1.45 \%$ on growth performance of amur common carp and mrigal with major carps in polyculture system. Mrigal from natural source revealed 2.0\% SGR (Biswas et al., 2008) ${ }^{[7]}$. Vhanalakar \& Muley, (2014) ${ }^{[41]}$ found that mrigal showed SGR of $1.17 \pm 0.03 \%$ in $40 \%$ plant protein. Mrigal did not show significant difference $(P>0.05)$ between T-I and T-II treatments and also between TC and T-III but T-I and T-II showed significant different $(p<0.05)$ from TC and T-III treatments.

The average daily growth rate of Jayanti rohu was highest in T-I treatment $(1.32 \pm 0.01 \mathrm{~g} /$ day $)$. Similar results for daily growth rate was also reported by Das Mahapatra, (2012) [9] while conducting farm field trial with $3^{\text {rd }}$ generation Jayanti rohu in West Bengal. Sarangi et al. (2004) ${ }^{[37]}$ also reported the daily growth rate of Jayanti rohu varied from 3.5 to 10.3 $\mathrm{g} / \mathrm{d}$ in different farms under organic culture. The average daily growth rate of Jayanti rohu shows significant difference among different treatments. The average daily growth rate of non-Jayanti rohu showed $0.97 \pm 0.01 \mathrm{~g} / \mathrm{day}$. Rai et al. (2010)
[29] reported average daily growth rate $1.41 \mathrm{~g} / \mathrm{day}$ of rohu while comparing growth and production of carp in polyculture ponds. Sah et al. (2018) ${ }^{[34]}$ found average daily growth rate $0.24 \mathrm{~g}$ /day of farmed rohu on comparative studied with genetically improved rohu. Das Mahapatra, (2012) ${ }^{[9]}$ reported average daily growth rate of local rohu (1.66 g/day) on farm field trial experiment with Jayanti rohu, catla and mrigal. The average daily growth rate of catla in different treatments reflected the results obtained for SGR. The present study showed that SGR and daily growth rate declined due to highest stocking density (Ronald et al., 2014) ${ }^{[31]}$. DoF (2010) ${ }^{[14]}$ observed the daily average weight gain of catla 0.391 $\mathrm{g}$ /day with mixture of rice bran and mustard oil cake (1:1) as supplemental feed fed at the rate $5 \%$ of total fish body weight daily. Rai et al. (2010) ${ }^{[29]}$ reported average daily growth rate $0.96 \mathrm{~g} /$ day of catla while comparing growth and production of carp in polyculture ponds. The average daily growth rate of catla not varied significantly $(P>0.05)$ in TC and T-II treatment while varied significantly with T-I and T-III treatment. For mrigal, the average daily growth rate was highest in TC $(0.78 \pm 0.01 \mathrm{~g} /$ day $)$ and T-III treatment $(0.78 \pm 0.01 \mathrm{~g} /$ day $)$ and lowest in T-I $(0.70 \pm 0.01 \mathrm{~g} /$ day $)$ and TII $(0.70 \pm 0.00 \mathrm{~g} / \mathrm{day})$ with same SD of $10 \%$. Das Mahapatra, (2012) ${ }^{[9]}$ reported average daily growth rate of 0.64-1.74 g/day on $10 \%$ SD. Rai et al. (2010) ${ }^{[29]}$ reported average daily growth rate $1.22 \mathrm{~g} /$ day of mrigal while comparing growth and production of carp in polyculture ponds. Mrigal did not show significant difference $(P>0.05)$ between T-I and T-II treatments and also between TC and T-III but T-I and T-II showed significant different $(p<0.05)$ from TC and T-III treatments.

When we looked in to the survivability rate of the experimented species, it was found that Jayanti rohu and mrigal showed $100 \%$ survivability rate in all the treatments, where such survivability rate on Jayanti rohu was also reported by Sarkar et al. (2015) ${ }^{[38]}$. Survival rate of nonJayanti in the present study was found to be $93.33 \pm 6.67 \%$. More or less similar results also obtained by Ahsan et al.

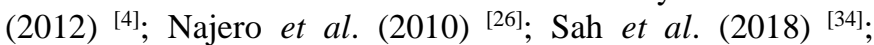
Ahmed, et al. (2012) ${ }^{[3]}$; Khan, et al. (2017) ${ }^{[6]}$ and Hafeez-urrehman, et al. (2006) ${ }^{[18]}$. The highest survival rate $(93.33 \pm 6.67 \%)$ of catla in the present study was observed to be in T-III and T-II treatment and survival was lowest with $(86.67 \pm 6.67 \%)$ was observed in T-I and TC treatment. The result of the survival rate was more or less similar to the reported values $86.01 \%$ to $94.4 \%$ (Ahsan et al. 2013) ${ }^{[5]}$ and $79.75 \%$ to $89.63 \%$ (Samad et al. 2017) ${ }^{[36]}$ and Biswas et al. (2008) ${ }^{[7]}$. Lower stocking density resulted in the highest survival rate when compared to higher densities (Costa et al. 2017) ${ }^{[8]}$. While Narejo et al. (2010) ${ }^{[26]}$ reported that survival was found to be negatively influenced by stocking densities. No significant difference $(P>0.05)$ was observed among different treatments on the survival rate. No mortality rate was observed in Mrigal and showed no significant difference $(P>0.05)$ in all the treatment. Similar result was reported by Hafeez-ur-rehman et al. (2006) ${ }^{[18]}$ and Rai et al. (2010) ${ }^{[29]}$ in polyculture.

The net production of Jayanti rohu was highest in T-I $2030.87 \pm 3.25 \mathrm{~kg} / \mathrm{ha}$ followed by T-III $(1984.48 \pm 3.25 \mathrm{~kg} / \mathrm{ha})$ and lowest in T-II $(1798.05 \pm 1.47 \mathrm{~kg} / \mathrm{ha})$ which showed significant difference $(P<0.05)$ among the treatments. Less net production of Jayanti rohu in T-II than T-III treatment was due to fact that stocking density may not have any influence on biomass (Costa et al. 2017) ${ }^{[8]}$. Similar results was obtained 
by Sah et al. (2018) [34] who reported that the yield of $(2223 \pm 82 \mathrm{~kg} / \mathrm{ha})$ for genetically improved rohu on comparative growth studies. The net production of nonJayanti rohu showed $1391.06 \pm 32.15 \mathrm{~kg} / \mathrm{ha}$ in the control treatment which revealed that non-Jayanti rohu had no better growth performance over Jayanti rohu. In contrast to the above findings, Sah et al. (2018) ${ }^{[34]}$ reported that genetically improved rohu had a superior performance on growth and yield over the farmed rohu. Sharma (2015) ${ }^{[39]}$ reported that the growth of Jayanti rohu in both the culture conditions such as monoculture and polyculture with carps outperformed the local rohu. Roy et al. (2013) ${ }^{[32]}$ reported that Jayanti rohu show superior performance in terms of body weight on both average and efficient farms. The net production of catla showed highest in T-II $(1781.37 \pm 40.30 \mathrm{~kg} / \mathrm{ha})$ with $50 \%$ SD and lowest in T-III $(1534.63 \pm 34.88 \mathrm{~kg} / \mathrm{ha})$ with $45 \% \mathrm{SD}$ and showed similar with the results of Abbas et al. (2010) ${ }^{[1]}$;
Prabaharan and Murugan, (2012) [27] and Ganesan et al. (2015) ${ }^{[17]}$. There showed no significant different $(p>0.05)$ among different treatments. The net production of mrigal showed highest in TC $(295.58 \pm 0.93 \mathrm{~kg} / \mathrm{ha})$ and lowest in T-II $(263.49 \pm 0.54 \mathrm{~kg} / \mathrm{ha}$. There showed no significant difference $(P>0.05)$ between T-I and T-II treatments and also between TC and T-III but T-I and T-II showed significant different $(p<0.05)$ from TC and T-III treatments.

From the above discussion it may be assumed that Jayanti rohu had a better growth performance even at different stocking densities compared to the non-Jayanti rohu. Furthermore, future studies must be carried out using newly produced generation of Jayanti rohu for evaluation of growth rate superiority over non-Jayanti rohu as rohu is one of the important species included in a commercial aquaculture system.

Table 2: Average growth (g) of Catla, non-Jayanti rohu, Jayanti rohu and Mrigal fingerlings in different treatments during the experimental period

\begin{tabular}{|c|c|c|c|c|c|c|c|c|c|c|c|c|}
\hline \multirow{3}{*}{$\begin{array}{c}\text { Sampling } \\
\text { Days }\end{array}$} & \multicolumn{12}{|c|}{ Treatment } \\
\hline & \multicolumn{3}{|c|}{ TC } & \multicolumn{3}{|c|}{ T- I } & \multicolumn{3}{|c|}{ T- II } & \multicolumn{3}{|c|}{ T- III } \\
\hline & Catla & NJR & Mrigal & Catla & JR & Mrigal & Catla & JR & Mrigal & Catla & JR & Mrigal \\
\hline 0 & $\begin{array}{c}9.79 \\
\pm 0.15\end{array}$ & $\begin{array}{c}9.52 \\
\pm 0.19\end{array}$ & $\begin{array}{c}8.62 \\
\pm 0.13 \\
\end{array}$ & $\begin{array}{c}9.82 \\
\pm 0.15\end{array}$ & $\begin{array}{c}8.52 \\
\pm 0.13 \\
\end{array}$ & $\begin{array}{c}9.23 \\
\pm 0.37 \\
\end{array}$ & $\begin{array}{c}9.44 \\
\pm 0.18\end{array}$ & $\begin{array}{c}8.14 \\
\pm 0.04\end{array}$ & $\begin{array}{c}8.53 \\
\pm 0.09 \\
\end{array}$ & $\begin{array}{c}9.73 \\
\pm 0.14\end{array}$ & $\begin{array}{c}8.66 \\
\pm 0.29 \\
\end{array}$ & $\begin{array}{c}8.70 \\
\pm 0.15\end{array}$ \\
\hline 15 & $\begin{array}{l}25.20 \\
\pm 0.25\end{array}$ & $\begin{array}{l}20.25 \\
\pm 0.42\end{array}$ & $\begin{array}{l}14.35 \\
\pm 0.23\end{array}$ & $\begin{array}{l}24.65 \\
\pm 0.38\end{array}$ & $\begin{array}{l}22.59 \\
\pm 0.12\end{array}$ & $\begin{array}{l}14.83 \\
\pm 0.61\end{array}$ & $\begin{array}{l}24.89 \\
\pm 1.28\end{array}$ & $\begin{array}{l}22.38 \\
\pm 0.28\end{array}$ & $\begin{array}{l}14.75 \\
\pm 0.60\end{array}$ & $\begin{array}{l}26.33 \\
\pm 0.24\end{array}$ & $\begin{array}{l}21.28 \\
\pm 0.07\end{array}$ & $\begin{array}{l}13.84 \\
\pm 0.64\end{array}$ \\
\hline 30 & $\begin{array}{c}40.3 \\
1 \pm 0.15 \\
\end{array}$ & $\begin{array}{l}38.41 \\
\pm 0.31 \\
\end{array}$ & $\begin{array}{c}26.6 \\
0 \pm 0.79\end{array}$ & $\begin{array}{l}39.41 \\
\pm 0.63 \\
\end{array}$ & $\begin{array}{l}49.23 \\
\pm 0.58 \\
\end{array}$ & $\begin{array}{l}20.78 \\
\pm 0.51 \\
\end{array}$ & $\begin{array}{l}41.11 \\
\pm 1.25 \\
\end{array}$ & $\begin{array}{l}47.54 \\
\pm 0.42 \\
\end{array}$ & $\begin{array}{l}25.73 \\
\pm 0.09 \\
\end{array}$ & $\begin{array}{l}41.33 \\
\pm 1.49 \\
\end{array}$ & $\begin{array}{l}45.47 \\
\pm 0.53 \\
\end{array}$ & $\begin{array}{l}25.15 \\
\pm 0.38 \\
\end{array}$ \\
\hline 45 & $\begin{array}{l}55.37 \\
\pm 1.29 \\
\end{array}$ & $\begin{array}{l}50.71 \\
\pm 1.81 \\
\end{array}$ & $\begin{array}{l}34.50 \\
\pm 0.56\end{array}$ & $\begin{array}{l}53.78 \\
\pm 0.58 \\
\end{array}$ & $\begin{array}{l}72.87 \\
\pm 0.35 \\
\end{array}$ & $\begin{array}{l}31.52 \\
\pm 0.32 \\
\end{array}$ & $\begin{array}{l}54.38 \\
\pm 0.76 \\
\end{array}$ & $\begin{array}{l}70.55 \\
\pm 0.39 \\
\end{array}$ & $\begin{array}{l}35.67 \\
\pm 0.23 \\
\end{array}$ & $\begin{array}{l}60.96 \\
\pm 0.83 \\
\end{array}$ & $\begin{array}{l}69.25 \\
\pm 0.09 \\
\end{array}$ & $\begin{array}{l}35.10 \\
\pm 2.55 \\
\end{array}$ \\
\hline 60 & $\begin{array}{l}70.56 \\
\pm 0.17 \\
\end{array}$ & $\begin{array}{l}65.23 \\
\pm 1.46 \\
\end{array}$ & $\begin{array}{l}47.12 \\
\pm 0.28 \\
\end{array}$ & $\begin{array}{l}68.42 \\
\pm 0.27 \\
\end{array}$ & $\begin{array}{l}84.55 \\
\pm 0.43 \\
\end{array}$ & $\begin{array}{l}50.70 \\
\pm 3.07 \\
\end{array}$ & $\begin{array}{l}69.71 \\
\pm 0.50 \\
\end{array}$ & $\begin{array}{l}83.57 \\
\pm 0.56 \\
\end{array}$ & $\begin{array}{l}45.97 \\
\pm 0.96 \\
\end{array}$ & $\begin{array}{l}75.64 \\
\pm 0.24 \\
\end{array}$ & $\begin{array}{l}80.26 \\
\pm 0.47 \\
\end{array}$ & $\begin{array}{l}52.94 \\
\pm 1.32 \\
\end{array}$ \\
\hline 75 & $\begin{array}{l}86.53 \\
\pm 0.38 \\
\end{array}$ & $\begin{array}{r}76.38 \\
\pm 2.87 \\
\end{array}$ & $\begin{array}{l}65.40 \\
\pm 0.32 \\
\end{array}$ & $\begin{array}{l}83.16 \\
\pm 0.91 \\
\end{array}$ & $\begin{array}{c}101.68 \\
\pm 0.08 \\
\end{array}$ & $\begin{array}{l}63.28 \\
\pm 1.24 \\
\end{array}$ & $\begin{array}{l}85.30 \\
\pm 0.31 \\
\end{array}$ & $\begin{array}{r}95.50 \\
\pm 3.41 \\
\end{array}$ & $\begin{array}{l}62.50 \\
\pm 1.65 \\
\end{array}$ & $\begin{array}{l}90.23 \\
\pm 0.16 \\
\end{array}$ & $\begin{array}{l}92.10 \\
\pm 1.32 \\
\end{array}$ & $\begin{array}{l}65.32 \\
\pm 0.21 \\
\end{array}$ \\
\hline 90 & $\begin{array}{l}101.10 \\
\pm 0.64\end{array}$ & $\begin{array}{l}96.72 \\
\pm 0.60 \\
\end{array}$ & $\begin{array}{l}79.00 \\
\pm 0.67 \\
\end{array}$ & $\begin{array}{l}98.31 \\
\pm 0.30 \\
\end{array}$ & $\begin{array}{c}127.29 \\
\pm 0.69 \\
\end{array}$ & $\begin{array}{l}72.26 \\
\pm 0.64 \\
\end{array}$ & $\begin{array}{l}100.3 \\
\pm 0.50 \\
\end{array}$ & $\begin{array}{c}113.26 \\
\pm 0.30 \\
\end{array}$ & $\begin{array}{l}71.27 \\
\pm 0.37 \\
\end{array}$ & $\begin{array}{l}105.93 \\
\pm 0.46 \\
\end{array}$ & $\begin{array}{l}103.16 \\
\pm 0.44 \\
\end{array}$ & $\begin{array}{l}78.92 \\
\pm 0.58 \\
\end{array}$ \\
\hline
\end{tabular}

Table 3: Details of fish growth $(\mathrm{g})$ in different treatments (pooled data)

\begin{tabular}{|c|c|c|c|c|c|c|c|c|c|c|c|c|}
\hline \multirow{3}{*}{ Parameters } & \multicolumn{12}{|c|}{ Treatment } \\
\hline & \multicolumn{3}{|c|}{ TC } & \multicolumn{3}{|c|}{ T- I } & \multicolumn{3}{|c|}{ T- II } & \multicolumn{3}{|c|}{ T- III } \\
\hline & Catla & NJR & Mrigal & Catla & JR & Mrigal & Catla & $\mathbf{J R}$ & Mrigal & Catla & JR & Mrigal \\
\hline & $\begin{array}{c}9.79 \\
\pm 0.15^{\mathrm{a}}\end{array}$ & $\begin{array}{c}9.52 \\
\pm 0.19^{\mathrm{b}}\end{array}$ & $\begin{array}{c}8.62 \\
\pm 0.13^{\mathrm{a}}\end{array}$ & $\begin{array}{c}9.82 \\
\pm 0.15^{\mathrm{a}}\end{array}$ & $\begin{array}{c}8.52 \\
\pm 0.13^{\mathrm{a}}\end{array}$ & $\begin{array}{c}9.23 \\
\pm 0.37^{\mathrm{a}}\end{array}$ & $\begin{array}{c}9.44 \\
\pm 0.18^{\mathrm{a}}\end{array}$ & $\begin{array}{c}8.14 \\
\pm 0.04^{\mathrm{a}}\end{array}$ & $\begin{array}{c}8.53 \\
\pm 0.09^{\mathrm{a}}\end{array}$ & $\begin{array}{c}9.73 \\
\pm 0.14^{\mathrm{a}}\end{array}$ & $\begin{array}{c}8.66 \\
\pm 0.29^{\mathrm{a}}\end{array}$ & $\begin{array}{c}8.70 \\
\pm 0.15^{\mathrm{a}}\end{array}$ \\
\hline & & $\begin{array}{c}96.72 \\
\pm 0.60^{\mathrm{a}}\end{array}$ & & & $\begin{array}{l}127.29 \\
\pm 0.69^{\mathrm{d}}\end{array}$ & $\begin{array}{r}72.26 \\
\pm 0.64^{\mathrm{a}}\end{array}$ & & & & $\begin{array}{l}105.93 \\
\pm 0.46^{\mathrm{c}}\end{array}$ & $\begin{array}{l}103.16 \\
\pm 0.44^{\mathrm{b}}\end{array}$ & $\begin{array}{c}78.92 \\
\pm 0.58^{\mathrm{b}}\end{array}$ \\
\hline $\begin{array}{c}\text { Mean weight } \\
\text { gain }(\mathrm{g})\end{array}$ & & $\begin{array}{c}87.19 \\
\pm 0.60^{\mathrm{a}}\end{array}$ & & & $\begin{array}{l}118.76 \\
\pm 0.57^{\mathrm{d}}\end{array}$ & & & & & & $\begin{array}{r}94.50 \\
\pm 0.46^{\mathrm{b}}\end{array}$ & $\begin{array}{c}70.22 \\
\pm 0.56^{\mathrm{b}}\end{array}$ \\
\hline FCR & $\begin{array}{c}1.42 \pm \\
0.01^{\mathrm{a}}\end{array}$ & $1.34 \pm 0.03^{b}$ & $\begin{array}{c}1.26 \pm \\
0.01^{\mathrm{a}} \\
\end{array}$ & $\begin{array}{l}1.42 \pm \\
0.01^{\mathrm{a}}\end{array}$ & $1.28 \pm 0.01^{\mathrm{a}}$ & $\begin{array}{l}1.36 \pm \\
0.04^{\mathrm{ab}}\end{array}$ & & $\begin{array}{l}1.35 \pm \\
0.00^{\mathrm{b}}\end{array}$ & $\begin{array}{l}1.39 \pm \\
0.02^{\mathrm{b}}\end{array}$ & $1.42 \pm 0.01^{\mathrm{a}}$ & $\begin{array}{l}1.56 \pm \\
0.01^{\mathrm{c}}\end{array}$ & $1.29 \pm 0.01^{\mathrm{ab}}$ \\
\hline $\operatorname{SGR}(\%)$ & $\begin{array}{c}2.08 \pm \\
0.02^{\mathrm{a}}\end{array}$ & $2.07 \pm 0.02^{\mathrm{a}}$ & $\begin{array}{l}1.98 \pm \\
0.02^{\mathrm{b}}\end{array}$ & $\begin{array}{c}2.05 \pm \\
0.01^{\mathrm{a}}\end{array}$ & $2.47 \pm 0.01^{\mathrm{c}}$ & $\begin{array}{l}1.81 \pm \\
0.05^{\mathrm{a}}\end{array}$ & $\begin{array}{l}2.11 \pm \\
0.03^{\mathrm{a}}\end{array}$ & $\begin{array}{l}2.40 \pm \\
0.00^{c}\end{array}$ & $\begin{array}{l}1.88 \pm \\
0.01^{\mathrm{a}}\end{array}$ & $2.13 \pm 0.01^{\mathrm{a}}$ & $\begin{array}{l}2.24 \pm \\
0.04^{\mathrm{b}}\end{array}$ & $1.97 \pm 0.02^{\mathrm{b}}$ \\
\hline $\begin{array}{l}\text { Avg. daily } \\
\text { growth }(\mathrm{g} / \mathrm{d})\end{array}$ & $\begin{array}{c}1.01 \\
\pm 0.01^{\mathrm{b}}\end{array}$ & $\begin{array}{c}0.97 \\
\pm 0.01^{\mathrm{a}}\end{array}$ & $\begin{array}{c}0.78 \\
\pm 0.01^{\mathrm{b}}\end{array}$ & $\begin{array}{c}0.98 \\
\pm 0.00^{\mathrm{a}}\end{array}$ & $\begin{array}{c}1.32 \\
\pm 0.01^{\mathrm{d}}\end{array}$ & $\begin{array}{c}0.70 \\
\pm 0.01^{\mathrm{a}}\end{array}$ & $\begin{array}{c}1.01 \\
\pm 0.01^{\mathrm{b}}\end{array}$ & $\begin{array}{c}1.17 \\
\pm 0.00^{\mathrm{c}}\end{array}$ & $\begin{array}{c}0.70 \\
\pm 0.00^{\mathrm{a}}\end{array}$ & $\begin{array}{c}1.07 \\
\pm 0.00^{c}\end{array}$ & $\begin{array}{c}1.05 \\
\pm 0.01^{\mathrm{b}}\end{array}$ & $\begin{array}{c}0.78 \\
\pm 0.01^{\mathrm{b}}\end{array}$ \\
\hline $\begin{array}{c}\text { Survival rate } \\
(\%)\end{array}$ & $\begin{array}{c}86.67 \\
\pm 6.67^{\mathrm{a}}\end{array}$ & $\begin{array}{c}93.33 \\
\pm 6.67^{\mathrm{a}}\end{array}$ & $\begin{array}{l}100.00 \\
\pm 0.00^{\mathrm{a}}\end{array}$ & $\begin{array}{c}86.67 \\
\pm 6.67^{\mathrm{a}}\end{array}$ & $\begin{array}{l}100.00 \\
\pm 0.00^{\mathrm{a}}\end{array}$ & $\begin{array}{l}100.00 \\
\pm 0.00^{\mathrm{a}}\end{array}$ & $\begin{array}{c}93.33 \\
\pm 6.67^{\mathrm{a}}\end{array}$ & $\begin{array}{l}100.00 \\
\pm 0.00^{\mathrm{a}}\end{array}$ & $\begin{array}{l}100.00 \\
\pm 0.00^{\mathrm{a}}\end{array}$ & $\begin{array}{c}93.33 \\
\pm 6.67^{\mathrm{a}}\end{array}$ & $\begin{array}{l}100.00 \\
\pm 0.00^{\mathrm{a}}\end{array}$ & $\begin{array}{l}100.00 \\
\pm 0.00^{\mathrm{a}}\end{array}$ \\
\hline $\begin{array}{c}\text { Gross Yield } \\
(\mathrm{kg} / \mathrm{ha})\end{array}$ & $\begin{array}{l}1841.02 \\
\pm 49.46^{\mathrm{a}} \\
\end{array}$ & $\begin{array}{c}1542.70 \pm \\
39.94^{\mathrm{a}} \\
\end{array}$ & $\begin{array}{l}331.80 \\
\pm 0.93^{\mathrm{b}} \\
\end{array}$ & $\begin{array}{l}1788.53 \\
\pm 44.09^{\mathrm{a}} \\
\end{array}$ & $\begin{array}{c}2176.58 \pm \\
3.95^{\mathrm{b}} \\
\end{array}$ & $\begin{array}{l}303.48 \\
\pm 0.90^{\mathrm{a}} \\
\end{array}$ & \begin{tabular}{|c|}
$1966.49 \pm$ \\
$44.64^{\mathrm{a}}$ \\
\end{tabular} & $\begin{array}{c}1937.26 \pm \\
1.68^{\mathrm{b}} \\
\end{array}$ & $\begin{array}{r}299.33 \\
\pm 0.52^{\mathrm{a}} \\
\end{array}$ & $\begin{array}{c}1689.78 \pm \\
38.25^{\mathrm{a}} \\
\end{array}$ & $\begin{array}{c}2166.29 \\
\pm 3.09^{\mathrm{b}} \\
\end{array}$ & $\begin{array}{l}331.48 \\
\pm 0.81^{\mathrm{b}} \\
\end{array}$ \\
\hline $\begin{array}{l}\text { Net Yield } \\
(\mathrm{kg} / \mathrm{ha})\end{array}$ & $\begin{array}{r}1662.72 \\
\pm 44.72^{\mathrm{a}}\end{array}$ & $\begin{array}{c}1391.06 \pm \\
32.15^{\mathrm{a}}\end{array}$ & $\begin{array}{l}295.58 \\
\pm 0.93^{\mathrm{b}}\end{array}$ & $\begin{array}{r}1610.20 \\
\pm 40.46^{\mathrm{a}}\end{array}$ & $\begin{array}{c}2030.87 \pm \\
3.25^{\mathrm{c}}\end{array}$ & $\begin{array}{r}264.70 \\
\pm 1.11^{\mathrm{a}} \\
\end{array}$ & $\begin{array}{c}1781.37 \pm \\
40.30^{\mathrm{a}}\end{array}$ & $\begin{array}{c}1798.05 \pm \\
1.47^{\mathrm{b}}\end{array}$ & $\begin{array}{r}263.49 \\
\pm 0.54^{\mathrm{a}} \\
\end{array}$ & $\begin{array}{c}1534.63 \pm \\
34.88^{\mathrm{a}}\end{array}$ & $\begin{array}{r}1984.48 \\
\pm 3.25^{\text {bc }}\end{array}$ & $\begin{array}{l}294.94 \\
\pm 0.78^{\mathrm{b}}\end{array}$ \\
\hline
\end{tabular}




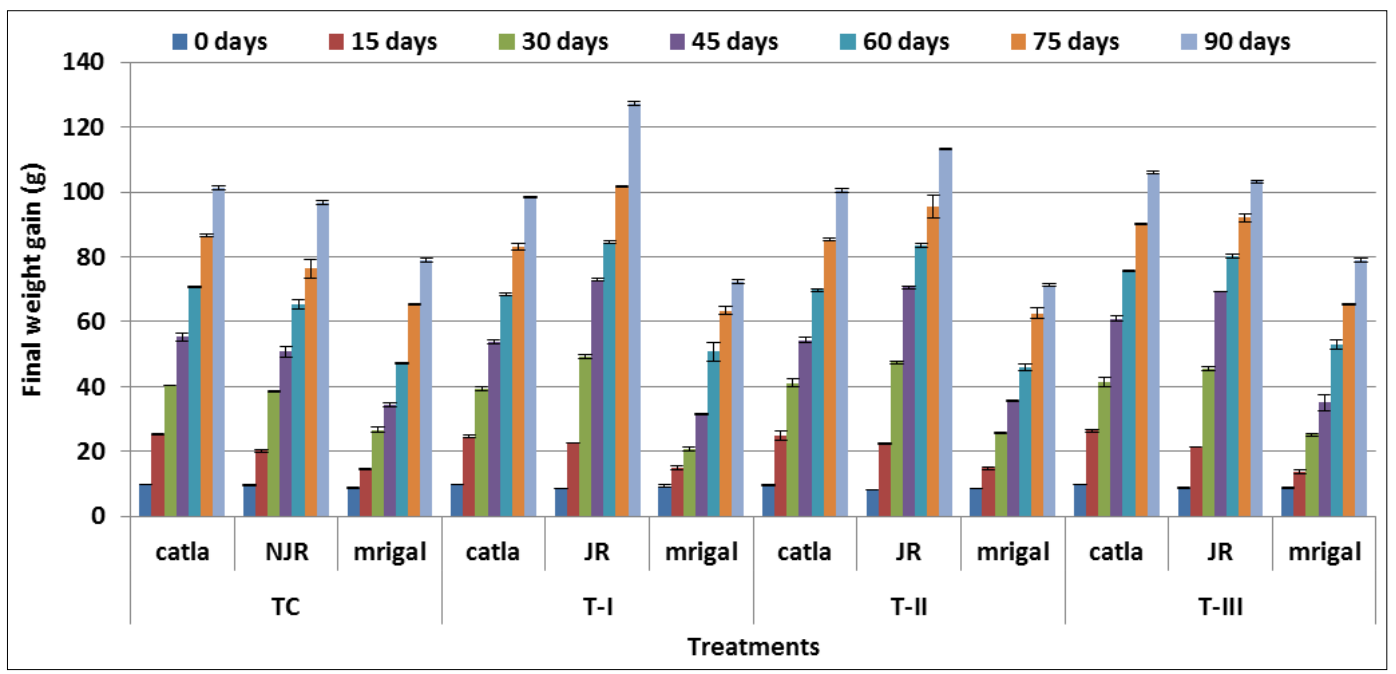

Fig 1: Final weight gain ( $g$ ) of different fish species in different treatments (mean \pm SE)

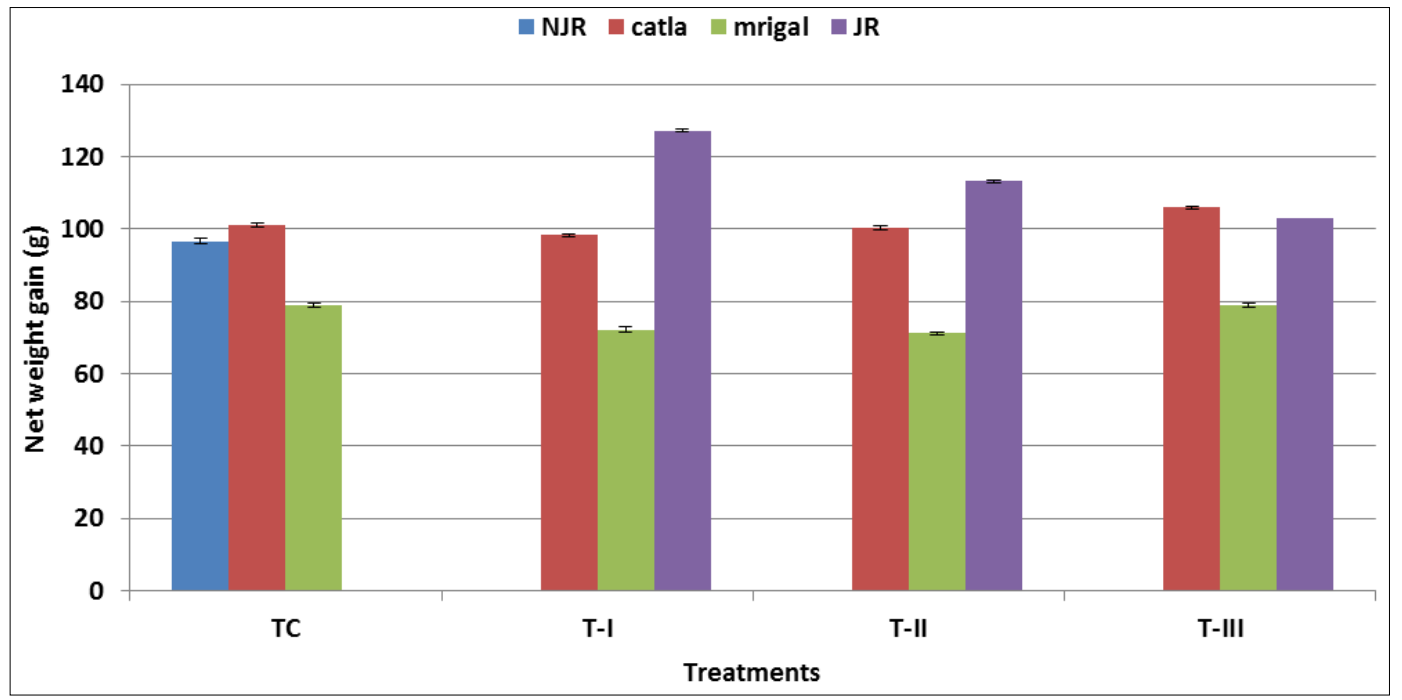

Fig 2: Net weight gain (g) of different fish species in different treatments (mean \pm SE)

\section{Acknowledgements}

Special thanks to the Dean; Head of Aquaculture Department; Department of Aquaculture and Aquatic Environment Management, College of Fisheries, Raha, Assam Agricultural University for their suggestions and help during the study.

\section{References}

1. Abbas S, Ahmed I, Salim M, Rehman K. Comparative effects of fertilization and supplementary feed on growth performance of three fish species. International Journal of Agriculture \& Biology 2010;12:276-280.

2. Abid M, Ahmed MS. Growth response of Labeo rohita fingerlings fed with different feeding regimes under intensive rearing. The Journal of Animal \& Plant Sciences 2009;19(1):45-49.

3. Ahmed MS, Shafiq K, Kian MS. Growth performance of major carp, Labeo rohita fingerlings on commercial feeds. The Journal of Animal \& Plant Sciences 2012;22(1):93-96.

4. Ahsan DA, Kabir AKNM, Rahman M, Mahabub S, Yesmin R, Faruque $\mathrm{H}$ et al. Plankton composition, abundance and diversity in hilsa (Tenualosa ilisha) migratory rivers of Bangladesh during spawning season. Dhaka Univ. J Biol. Sci 2012;21(2):177-189.

5. Ahsan ME, Wahab MA, Siddik MAB, Alam MA, Sharker MR, Nahar A. Impacts of inclusion of column feeder rohu (Labeo rohita) at different stocking densities on growth, production and environment in freshwater prawn-carp-mola polyculture system. International Journal of Biological Research 2013;1(2):48-54.

6. Basak SS, Rahman Md. M, Bahsar Md. A, Khan Md. MH, Mahmud, Md Y. Production and growth performance under carp polycuture with different stocking densities in hilly creeks of Kaptai Lake, Rangamati. MOJ Ecology \& Environmental Science 2017;2(4):4-5.

7. Biswas BK, Shah S, Takii K, Kumai H. A comparison of growth performance of Indian major carps, Catla catla (Hamilton) and Cirrhinus cirrhosus (Bloch) from natural and hatchery sources in Bangladesh. Aquaculture Sci 2008;56(2):245-251.

8. Costa AAP, Roubach R, Dallago BSL, Bueno GW, McManus C, Bernal FEM. Influence of stocking density on growth performance and welfare of juvenile tilapia (Oreochromis niloticus) in cages. Arq. Bras. Med. Vet. Zootec 2017;69(1):243-251.

9. Das Mahapatra K. Principles and practices of selective breeding in rohu (Labeo rohita). In: Quality fish seed production through brood fish management in SAARC countries Das Mahapatra K, Routray P, Barik NK, Jayasankar P. (eds) 2012, 67-76, India.

10. Das Mahapatra K, Jana RK, Saha JN, Gjerde B, Sarangi 
N. Lessons from the breeding program of rohu. In: Development of aquatic animal genetic improvement and dissemination programs: current status and action plans. World Fish Center Conference Proceedings, 73. World Fish Center 2006, 34-40. Penang, Malaysia.

11. Das Mahapatra K, Jayasankar P, Saha JN, Murmu K, Rasal AR, Nandanpawar P et al. Jayanti Rohu: Glimpses from the Journey of First Genetically Improved Fish in India, 1st edn. ICAR-CIFA, Bhubaneswar 2016.

12. Das Mahapatra K, Saha JN, Sarangi N, Jana RK, Gjerde $\mathrm{B}$, Nguyen $\mathrm{NH}$ et al. Genetic improvement and dissemination of rohu (Labeo rohita Ham.) in India. Proc. Assoc. Advmt. Anim. Breed. Genet 2007;17:37-40.

13. Dey MM, Kumar P, Paraguas FJ, Chen OL, Khan MA, Srichantuk N. Performance and nature of genetically improved carp strains in Asian countries. Aquaculture Economics \& Management 2010;14(1):3-19.

14. DoF, Jatio Matshaw Saptah. Department of Fisheries 2010, 104-108.

15. Eatson AD, Clesceri LS, Rice EW, Greenberg AE. In: APHA: Standard methods for the examination of water and wastewater, $21^{\text {st }}$ ed. American Public Health Association, Washington, D.C 2005.

16. FAO. National Aquaculture Sector Overview India 2014, 2.

17. Ganesan R, Manivelu D, Chennakrishnan C. Study, to assess the influence of supplementary feeding methods in different combinations on growth performance of Catla catla (F. Hamilton, 1822) and Labeo rohita (F. Hamilton, 1822). International Journal of Scientific Engineering and Applied Science (IJSEAS) 2015;1(6):389-400.

18. Hafeez-ur-rehman M, Ahmed I, Javid A, Akhtar HMN. Comparative growth and yield of exotic chinese and indigenous major carps under polyculture system. Journal of Agriculture \& Social Sciences 2006;2(4):256-259.

19. Haque MT, Ahmed ATA. Spawning periodicity of two Indian major carps, Labeo rohita (Ham.) and Cirrhinas mrigala (Ham.). Bangladesh Journal of Zoology 1993;21(2):9-26.

20. Hussain SM, Shahzad MM, Jabeen F, Nasir S, Afzal M, Javid A et al. Growth performance and nutrient digestibility of Cirrhinus mrigala fingerlings fed on soybean meal-based diet supplemented by phytase. International Journal of Biosciences 2014;5(12):212-221.

21. Jahan DA, Hussain L, Islam MA, Naima A. Evaluation of Soybean Meal as a Dietary Protein Source on the Performance of Labeo rohita (Ham.) Spawn Reared under Pond Condition. The Agriculturists 2013;11(2):1420.

22. Khan MA, Qasam I, Hussain S. Growth performance of Freshwater Labeo rohita (Hamilton, 1822) fed with commercial, supplementary plant and animal feeds. Journal of Entomology and Zoology Studies 2017;5(3):1198-1200.

23. Kohinoor AHM, Hasan MA, Thilsted SH, Wahab SH. Culture of small indigenous fish species (SIS) with Indian major carps under semi-intensive culture system. Indian J Fish 2005;52(1):23-31.

24. Kumar P, Dey MM, Barik NK. Farm economics of genetically improved carp strains in major Asian countries and carp seed price policy mode. Agricultural Economics Research Review 2008;21:395-406.

25. Manomaitis L, Cremer MC, Anand PEV. Growth performance of rohu carp in ponds using the ASA feed- based technology with soy-maximized feed compared to the India National Package Methodology. American Soybean Association 12125 Woodcrest Executive Drive, Suite 100 St. Louis, MO 63141 USA 2004, 1-5.

26. Narejo NT, Dayo A, Dars BA, Mahesar H, Laghari MY, Lashari PK. Effect of stocking density on growth and survival rate of Labeo rohita (Hamilton) fed with formulated feed. Sindh Univ. Res. Jour. (Sci. Ser.) 2010;42(1):35-38.

27. Prabaharan C, Murugan AS. A study on effects of fertilization and supplementary feed on growth performance of three Indian Major Carps. International Journal of Pharmaceutical \& Biological Archives 2012;3(1):186-191.

28. Priya Darsini DT, Maheshu V, Srinivasan P, Babu JD, Castro J, Sasikumar JM. Growth efficacy and Feed utilization of fresh water Fishes Cirrhinus mrigala (Ham.) and Cyprinus carpio L. fed with Limonia acidissima L. Research Journal of Recent Sciences 2014;3:127-131.

29. Rai S, Yi Y, Wahab Md. A, Bart AN, Diana JS. Comparison of the growth and production of carps in polyculture ponds with supplemental feed using rice straw and Kanchi as substrates. Our Nature 2010;8:92105.

30. Reddy PVGK. Genetically improved varieties to enhance production with special reference to modern aquaculture. Consideration of pros and cons aspects. In: Final Workshop on Genetic Improvement of Rohu (Labeo rohita Ham.) for Growth through Selective Breeding. Genetics and Biotechnology Division, May, 20-21. 2003, 26-34. CIFA, Bhubaneshwar, India,

31. Ronald N, Gladys B, Gasper E. The effects of stocking density on the growth and survival of Nile Tilapia (Oreochromis niloticus) fry at Son Fish Farm, Uganda. J Aquac Res Development 2014;5(2):1-7.

32. Roy SD, Ray BC, Sankar RK. Towards diversification of aquaculture in Andaman and Nicobar islands with Jayanti rohu (CIFA IR 1). Journal of the Andaman Science Association 2013;18(2):131-134.

33. Sachan Y, Shyama S, Yadav RP, Uchoi R, Sreenath VR. Growth response of Catla (Catla catla) fed Vegetable and fruit processing Waste based Diets. Research Journal of Animal, Veterinary and Fishery Sciences 2016;4(2):7-12.

34. Sah U, Mukhiya Y, Wagle SK. Comparative evaluation of genetically improved and farmed rohu (Labeo rohita) on growth and yield at initial stage of rearing. International Journal of Fisheries and Aquatic Studies 2018;6(2):47-50.

35. Sahoo M, Mukhopadhyay PK. Dietary ascorbic acid requirements of fingerlings of genetically improved rohu (Labeo rohita Ham). The Israeli Journal of Aquaculture Bamidgeh 2008;60(2):100-106.

36. Samad Md. A, Rahman Md. M, Paul AK, Rashid Md. A. Growth and production of riverine Catla catla (Hamilton, 1822) fry in pond habitat based on stocking density. International Journal of Fisheries and Aquatic Studies 2017;5(3):414-419.

37. Sarangi N, Kumaraiah P, Rangacharyulu PV, Giri BS. Status of Freshwater Aquaculture in Krishna-Godavari delta a profile. CIFA (ICAR) 2004, 11-12.

38. Sarkar S, Mohanty SN, Nayak KC, Pradhan C, Mohanta KN, Devaraj C. Protein requirement of IR- Jayanti (Labeo rohita) Fingerlings. International Journal of 
Fisheries and Aquatic Studies 2015;3(2):324-330.

39. Sharma DJ. Capacity building for the base line workers in fisheries sector with special reference to production of farmed fish 2015, 1-20.

40. Verma HO, Mandal SC. Evaluation of growth performance of amur common carp (Cyprinus carpio) and mrigal (Cirrhinus mrigala) with major carps in polyculture system. Journal of Entomology and Zoology Studies 2018;6(2):2277-2281.

41. Vhanalakar SA, Muley DV. Effect of dietary incorporation of Gliricidia maculata leaf meal on growth and feed utilization of Cirrhinus mrigala fingerlings. Global Journal of Science Frontier Research Biological Science 2014;14(1):47-49. 